\title{
Productive evaluation of slow-growing Mexican turkeys with different diets in confinement
}

\author{
Elizabeth Pérez-Lara ${ }^{1}$, Marco Antonio Camacho-Escobar ${ }^{2^{*}}$, Narciso Ysac Ávila-Serrano ${ }^{2}$, \\ Jaime Arroyo-Ledezma ${ }^{2}$, Edgar Iván Sánchez-Bernal ${ }^{2}$, Mabel Rodríguez-dela Torre ${ }^{2}$, \\ Virginia Reyes-Borques ${ }^{2}$ \\ ${ }^{1}$ Chila’s Bajos, Mixtepec, Oaxaca, México \\ ${ }^{2}$ Cuerpo Académico Ciencias Agropecuarias, Universidad del Mar, Campus Puerto Escondido, Puerto Escondido, México; \\ *Corresponding Author: marcama@zicatela.umar.mx
}

Received 26 September 2012; revised 26 October 2012; accepted 17 November 2012

\begin{abstract}
Were assessed the effect of five traditional diets backyard turkeys in confinement. The experiment lasted 36 weeks, the turkeys were randomized to one of five diets: kitchen waste + fresh forage (T1), kitchen waste (T2), commercial feed + fresh forage (T3), cracked corn + fresh forage (T4) and commercial feed (T5). Food and water were provided ad libitum. Each treatment with birds of both sexes had two repetitions with four birds and each bird was considered as an experimental unit were evaluated daily weight gain, total weight gain, final live weight, total length peak-tail, monthly gain peak-tail, total length, total length of wings, monthly gain wings length, and feed cost. The data were analyzed in a completely randomized arrangement with adjusted means and Tukey's mean comparison, then an evaluation of treatment groups by analyzing clusters for semi quantitative data. The biggest daily gain, total weight gain and final live weight was obtained with treatment $\mathrm{T} 3$, while the highest increase in peak-length tail and wings was obtained with treatment T1 $(P<0.05)$. T2 treatment turned out to be most economical, but the treatment that best scores obtained was T1. We conclude that the use of kitchen waste + fresh forage is a feasible strategy to feed slowgrowing turkeys.
\end{abstract}

Keywords: Creole Turkey; Cost of Feed; Fresh Forage; Guajolote; Meleagris Gallopavo; Traditional Diets

\section{INTRODUCTION}

The turkey breeding and production slow-growing na- tive or Creole, in Mexico, is a good choice for families with limited resources farmers obtain animal protein of high quality, but is not considered a major zootechnical activity [1]. The production of slow-growing turkey has the advantage of being semi-rustic, therefore birds provides a wide range of adaptation to different climates and natural resistance against diseases [2], since it has shown its ability to develop antibodies against some diseases that are naturally exposed [3]. These factors give them greater hardiness and ability to adapt to the need little care [4]. It has been previously reported that in certain regions of Oaxaca, the turkeys are raised in semi grazing conditions with little or no health control [3,5]. The backyard turkey feed is based primarily on corn, tortilla and its products, but also includes: fruits, vegetables, kitchen waste, commercial food, various grains, grazing and insects [6-8]. The various types of feed traditionally used in turkeys, causing different body development [1] and causes that the organoleptic characteristics of meat be different [9]. Because the production of slow-growing turkeys is practiced almost exclusively by peasants and indigenous people, have been little studied. The information generated to describe the production of native turkeys in Mexico is incomplete and does not include economic analysis, Contino-Esquijerosa [10] has pointed out that in studies designed under an exclusively biological vision, partial conclusions can be derived, as recommended in some cases, dietary proposals technically feasible, but not feasible from the economic standpoint. It is therefore very important to assess the economic feasibility of using different feeding treatments slow-growing turkeys. The objective of this study is to evaluate the effect that some of the traditional food systems compared to commercial feed, relative to growth, relating weight gain, body development, in addition to estimating the cost of turkey feed, to determine which treatment is most suitable for the slow-growing native turkeys raised in confinement. 


\section{MATERIAL AND METHODS}

The research was conducted in the Experimental Field of the Universidad del Mar (UMAR), in Puerto Escondido, Oaxaca, Mexico. Fifty turkeys of bronze phenotype, mixed, slow growing and three months old, were acquired with backyard producers in rural communities in the region. Poults were selected with the phenotype of their parents, who were always bronze color and delayed corporal development. Arriving turkeys in the experimental field, had a week of adaptation, and then were randomized to start the experiment. They were housed in cages of $9 \mathrm{~m}^{2}$, with cement floor and walls mesh. The cages were equipped with two trays of initiation, two plastic sprues for $3 \mathrm{~L}$, a feeding hopper, and hangers' stainless steel tubes each. They were given vaccines for fowl cholera, fowl pox, avian influenza and Newcastle, according to the description of most common diseases in turkeys in the area [11]. Each turkey was individually marked with colored plastic beads, which were placed on the skin of the occipital region of the head, each color had a corresponding number, and it is a temporary identication method recommended for wildlife research [12]. The experimental phase lasted 35 weeks, and all the exrimental phase was performed following animal welfare criteria imposed by the University Research Council, which are governed by the Official Mexican Standard NOM-062-ZOO-1999, entitled "Technical specifications for production, care and use of laboratory animals" [13].

\subsection{Description of the Diets Used}

In each experimental treatment consisted of two cages with 5 turkeys, each turkey was considered an experimental unit. The feeding system for all experimental units was to provide one of the treatments: $\mathrm{T} 1=$ kitchen waste + fresh forage, $\mathrm{T} 2=$ kitchen waste, $\mathrm{T} 3=$ commercial feed for turkeys + fresh forage, $\mathrm{T} 4=$ cracked corn + fresh forage, and $\mathrm{T} 5$ = commercial feed for turkeys, which served as control (Table 1). The kitchen waste is offered in trays, broken corn and turkeys in commercial food hopper feeders, fresh forage was offered freshly cut and placed in locations accessible to the turkeys. The forage used was the guinea grass (Panicum maximum), in a young phenological stage (less than $20 \%$ bloom). The idea of providing diets with different nutrient density, was taken from a study by Hale et al. [14], who evaluated the inclusion of $5 \%, 10 \%, 15 \%$ and $20 \%$ of fiber in the diet of in captivity domestic turkeys, and report that as the level of fiber, the caloric content in the diet decreased, but turkeys adjusted feed intake, eating more low-calorie food and at the end of the experiment there were no significant differences in weight gain.

Feed and water were offered ad libitum. Every day was weighed the feed offered and refused, which was obtained by difference daily intake, weekly turkeys were weighed with an electronic scale platform Torrey ${ }^{\circledR}$ trademark EQB1007/200 model, with capacity of $50 \mathrm{~kg}$ and $200 \mathrm{~g}$ precision, measurements were made of head-tail and wingspan with a flexible tape Urrea ${ }^{\circledR}$ trademark with length of $100 \mathrm{~cm}$, to estimate the weekly weight gain, which was obtained by weight difference obtained the previous week, likewise was estimated weekly increase in peak-tail length and wingspan.

The diet was based on waste of kitchen variety of ingredients contained in good state of preservation, and to determine their frequency 60 samples were taken randomly, two each week, and watch the content of the samples to determine the percentage of each ingredient, Table 2. Respects to commercial diets were used two stages: initiation (crumbs) for three months, and ending in pellets, for turkeys with more than six months old.

The proximal analyses of the treatments were performed in the laboratory of food using standardized methods [15]. Regarding the commercial feed for turkeys include values that the manufacturer included on the label and the values were ascertained by proximate analysis.

Table 1. Chemical composition of the diets used in the experiment ${ }^{*}$.

\begin{tabular}{lccccc}
\hline \multirow{2}{*}{ Variable } & \multicolumn{5}{c}{ Tratment } \\
\cline { 2 - 5 } & $\mathbf{T 1}$ & $\mathbf{T 2}$ & $\mathbf{T 3}$ & $\mathbf{T 4}$ & $\mathbf{T 5}$ \\
\hline Dry matter & 42.70 & 34.00 & 85.90 & 88.94 & 88.00 \\
Humidity & 57.30 & 66.00 & 14.10 & 11.06 & 12.00 \\
Crude protein & 13.77 & 13.97 & 26.24 & 7.80 & 25.00 \\
Ether extract & 8.86 & 11.00 & 2.60 & 4.96 & 3.50 \\
Fibrer & 18.90 & 15.20 & 12.19 & 11.28 & 7.40 \\
Nitrogen free extract & 54.09 & 56.73 & 47.98 & 57.91 & 53.40 \\
Ash & 4.38 & 3.10 & 10.99 & 0.64 & 10.80 \\
\hline
\end{tabular}

*The composition which includes fresh forage as a source of variation was estimated at a ratio of 4:1 food-forage. All results are expressed as percentages. $\mathrm{T} 1=$ kitchen waste + fresh forage; $\mathrm{T} 2=$ kitchen waste; $\mathrm{T} 3=$ commercial feed for turkeys + fresh forage; T4 = cracked corn + fresh forage; and T5 = commercial feed for turkeys. 
Table 2. Frequency of occurrence in diet ingredients from kitchen waste ${ }^{1}$.

\begin{tabular}{|c|c|}
\hline Ingredient & Frequency (\%) \\
\hline Lettuce & 18 \\
\hline Cabbage & 16 \\
\hline Raw tomato & 15 \\
\hline Corn tortilla & 11 \\
\hline Oats & 10 \\
\hline Beans & 8 \\
\hline Bread or flour products & 6 \\
\hline Broccoli & 6 \\
\hline Rice & 4 \\
\hline Carrot & 1 \\
\hline Baby corn & 1 \\
\hline Pea & 1 \\
\hline Chicken meat & 1 \\
\hline Cheese & 1 \\
\hline Egg & 0.5 \\
\hline Beef & 0.5 \\
\hline
\end{tabular}

${ }^{1}$ Proximal analysis prepared with 60 random samples of kitchen waste as feed offered.

\subsection{Economic Analysis}

To estimate power cost was considered the price per kilogram of food trade in the region which was $\$ 0.55$ USD, the selling price of cracked corn was \$0.60 USD. To estimate the cost of kitchen waste weekly was considered the price of bagging to $\$ 0.37$ USD. It also included a cost for labor for cutting and harvesting of fresh forage based on 60 minutes of work as time dedicated daily to get fresh forage (\$0.48 USD) and was related with the minimum daily wage was paid in region $(\$ 3.87$
USD/day). Cost calculations were estimated in US dollars, with an exchange rate of $\$ 12.83$ pesos per US dollar. The method used for determining the cost of feed was adjusted to that used by Jerez et al. [16].

\subsection{Statistical Analysis}

We conducted a completely randomized design with 5 treatments and 10 repetitions, each treatment had two cages containing five birds, each individually turkey was considered as experimental unit. The results were evaluated using the program statistical SAS [17] through the GLM procedure. To eliminate any possible error attributable to differences in weight and size that could have turkeys at the beginning of the experiment, the mean weight were adjusted for initial weight as a covariate, while the average peak-tail length and wingspan for his respective initial measures, it through the function arcsin $\sqrt{x}$ [18]. Subsequently applied the test for Tukey's means comparison, considering $\mathrm{P}<0.05$ as significant difference. For the evaluation of the experimental treatments was carried to elaborate a numerical classification conglomerate groups analysis for semi-quantitative data [19]. It was integrated a matrix of all variables studied and taken as reference an ideal location with a total score of 27 points, for the variables daily gain, total weight gain, final live weight, total length-tail peak, monthly gain peak-tail length, total length and monthly gain length wings were considered likely to compare Tukey's means: $\mathrm{A}=3, \mathrm{AB}=2, \mathrm{~B}=1$. For the variable feeding cost was considered the range of 1 to $100=3,101$ to 200 $=2,201-300=1$. The cost per kg of body weight was evaluated considering the range of 1 to $20=3,21$ to $40=$ 2,41 to $60=1$. The total score of the treatments was estimated to range $9-14=$ poor, $15-20=$ fair, $21-27=$ good.

\section{RESULTS AND DISCUSSION}

Table 3 presents the results of daily gain, total weight gain and final live weight of the slow-growing turkeys.

Table 3. Mean of daily weight gain, total weight gain and final live weight of turkeys of slow growth with different experimental diets.

\begin{tabular}{cccc}
\hline Treatment & Daily weight gain $(\mathbf{g})$ & Total weight gain $(\mathbf{g})$ & Final live weight (g) \\
\hline T1 & $11.0^{\mathrm{ab}}$ & $2904.4^{\mathrm{ab}}$ & $5817.5^{\mathrm{a}}$ \\
T2 & $5.9^{\mathrm{b}}$ & $1623.9^{\mathrm{ab}}$ & $4777.5^{\mathrm{ab}}$ \\
T3 & $15.3^{\mathrm{a}}$ & $3908.5^{\mathrm{a}}$ & $6461.3^{\mathrm{a}}$ \\
T4 & $3.4^{\mathrm{b}}$ & $908.1^{\mathrm{b}}$ & $2982.5^{\mathrm{b}}$ \\
T5 & $10.5^{\mathrm{ab}}$ & $2887.5^{\mathrm{ab}}$ & $4976.5^{\mathrm{ab}}$ \\
\hline
\end{tabular}

$\mathrm{T} 1$ = kitchen waste + fresh forage; $\mathrm{T} 2$ = kitchen waste; $\mathrm{T} 3$ = commercial feed for turkeys + fresh forage; $\mathrm{T} 4$ = cracked corn + fresh forage; and T5 = commercial feed for turkeys; ${ }^{\mathrm{a}, \mathrm{b}, \mathrm{c}}$ Columns with different letter are different $(\mathrm{P}<0.05)$. 
Respect to daily weight gain, treatment of commercial food + fresh forage (T3) had the best performance with average increase production more than $9 \mathrm{~g} / \mathrm{d}$ compared to the gain of treatments with less weight gain, who were the turkeys with cracked corn + fresh forage (T4) and kitchen waste (T2), these differences were statistically significant $(\mathrm{P}<0.05)$. The total weight gain, $\mathrm{T} 3$ treatment had a weight of $3000 \mathrm{~g}$ more than T4 treatment and this difference was statistically $(\mathrm{P}<0.05)$. For the variable final live weight, the best treatments were comercial feed + fresh forage (T3) and kitchen waste + fresh forage (T1), both treatments were significantly different $(\mathrm{P}<0.05)$ than those of turkeys fed cracked corn forage + fresh (T4).

Two morphometric variables for the selection of broodstock, are measures of the total peak-tail length and wingspan, which together give an idea of the overall size of the turkey. These variables are presented in Table 4. Turkeys fed kitchen waste + fresh forage (T1) and commercial feed $(\mathrm{T} 5)$ had greater $(\mathrm{P}<0.05)$ total peak-tail length compared to treatment with cracked corn + fresh forage (T4), however when determining monthly gain peak-tail length, only $\mathrm{T} 1$ was statistically higher $(\mathrm{P}<$ 0.05 ) than other treatments. With respect to the total size of the wings, the turkeys with cracked corn + fresh forage (T4) showed the smallest, statistically significant ( $P$ $<0.05$ ) than those who consumed kitchen waste (T1 and
T2) and commercial feed (T5). The monthly gain in wingspan, was greater in the treatment of kitchen waste + fresh forage, compared to all other treatments, this difference was significant $(\mathrm{P}<0.05)$.

The accumulated gain performance of that showed different treatments during the experiment shown in Figure 1. It is notable that the treatments were segmented in three: kitchen waste (T2) and cracked corn + fresh forage (T4) had the lowest overall cumulative gain. An intermediate segment in which treatments are kitchen waste + fresh forage (T1) and commercial feed for turkeys (T5) form the intermediate segment and finally, the best treatment was commercial feed for turkeys + fresh forage.

It seems evident that the addition of fresh forage to the diet helps improve growth performance of the slowgrowing turkeys. This is observed by the behavior that had the commercial food + fresh forage (T3) that was what propitiated the greatest cumulative weight gain. Similar effect was in the kitchen waste + fresh forage (T1), which produced the cumulative weight gain, was even higher than that obtained by the commercial feed (T5). There is a favorable effect on weight gain in the presence of forage in the diet, both the commercial feed for turkeys as kitchen waste, improved their growth performance to add it. In the case of cracked corn, it is clear that its combination with fresh forage, only met the

Table 4. Means in millimeters of the total length-tail peak (TPTL) monthly gain peak-tail length (MGPTL), total size of wings (TSW) and wingspan monthly gain (WMG) in slow-growing turkeys with different diets.

\begin{tabular}{ccccc}
\hline Treatment & TPTL & MGPTL & TSW & WMG \\
\hline T1 & $107.1^{\mathrm{a}}$ & $5.1^{\mathrm{a}}$ & $134.8^{\mathrm{a}}$ & $6.2^{\mathrm{a}}$ \\
T2 & $104.6^{\mathrm{ab}}$ & $1.8^{\mathrm{b}}$ & $129.1^{\mathrm{a}}$ & $1.8^{\mathrm{b}}$ \\
T3 & $100.1^{\mathrm{ab}}$ & $1.5^{\mathrm{b}}$ & $127.1^{\mathrm{ab}}$ & $1.1^{\mathrm{b}}$ \\
T4 & $92.6^{\mathrm{b}}$ & $0.5^{\mathrm{b}}$ & $117.8^{\mathrm{b}}$ & $0.9^{\mathrm{b}}$ \\
T5 & $106.0^{\mathrm{a}}$ & $2.3^{\mathrm{b}}$ & $129.1^{\mathrm{a}}$ & $2.7^{\mathrm{b}}$ \\
\hline
\end{tabular}

T1 = kitchen waste + fresh forage; T2 = kitchen waste; T3 = commercial feed for turkeys + fresh forage; $\mathrm{T} 4$ = cracked corn + fresh forage; and $\mathrm{T} 5$ = commercial feed for turkeys; ${ }^{\mathrm{a}, \mathrm{b}, \mathrm{c}}$ Columns with different letter are different $(\mathrm{P}<0.05)$.

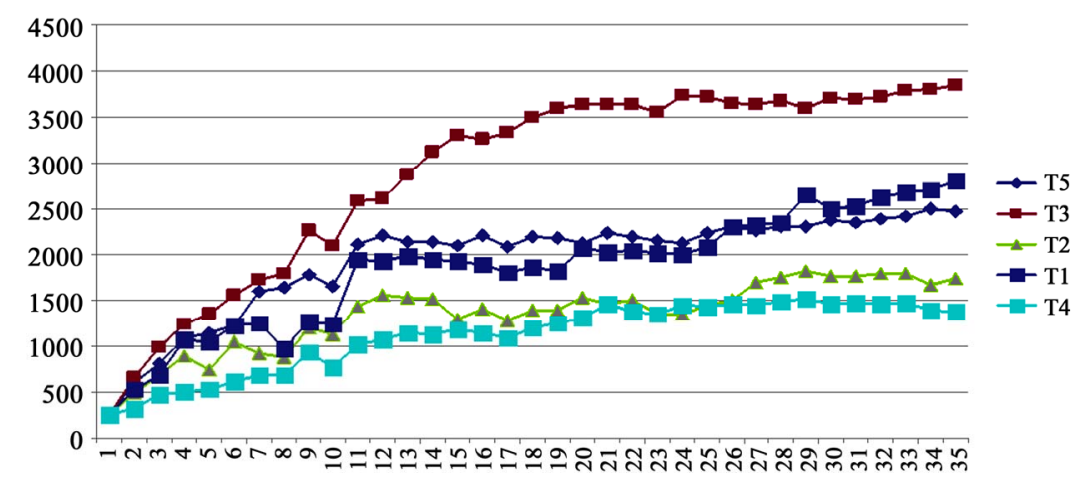

Figure 1. Cumulative means weight gain (g) of slow-growing turkeys. T1 = kitchen waste + fresh forage; $\mathrm{T} 2=$ kitchen waste; $\mathrm{T} 3=$ commercial feed for turkeys + fresh forage; $\mathrm{T} 4$ = cracked corn + fresh forage; and T5 = commercial feed for turkeys. 
needs of maintenance from the 20th week of the experiment, inferring that this feeding strategy yields the maximum weight at 32 weeks of age.

Considering that commercial feed for turkeys is formulated according to their nutritional needs, the best growth performance may possibly be related to the slowgrowing turkeys have different nutritional needs and require the presence of green forage to exploit the ability of feeding with forage have slow growing turkeys, as in wild turkeys [6], and in this manner optimize the digestive process. Sarmiento et al. [20] suggest that even small quantities of green fodder as protein supplements in diets low in protein, can have nutritional importance, at least for backyard birds.

Similar to the present results, reported in a study by adding different types of fodder to poultry diets, where he found highly significant differences in weight gain [21]. Even though the contributions of forage protein and energy were low, concludes that differences in weight are due to forage contributed significant amounts of minerals and carotene, a precursor of vitamin A.

In a study of the anatomy and physiology of birds, was concluded that the feeding strategy of turkeys are omnivorous, and under natural conditions, not fed only grains [22], which is consistent with the findings of this study and explains partially the result to be had with the kitchen waste, which includes different types of ingredients (Table 2).

There is controversy about the efficiency with poultry in the use of foods rich in fiber [20]. It was hypothesized that extensive management system without access to concentrates, has resulted in the development of a greater ability to digestion and fermentation of forage high in fiber, with a better efficiency in the absorption of nutrients available (amino acids, minerals, vitamins, energy) [23]. In Oaxaca, usually raising turkeys of slow growth is extensive, the birds feed in large proportion with fresh forage, optimizing their digestibility [1]. It has been estimated that poultry on pasture come to consume $5 \%$ to $20 \%$ forage, depending on the age and quality of forage [24].

In this study, treatment of kitchen waste + fresh forage (T1), had a content of $18.9 \%$ fiber, the highest value compared to the other treatments (Table 1). However, it was found that despite the high level of fiber, weight gain is not affected, but there was an increase in feed conversion, due to increased feed intake, as has been previously reported [14].

This favorable response in the growth of the poultry and egg hatchability, caused by the addition of fresh forage, has been called "grass factor" [25]. However, HuertaRuiz et al. [26] found no significant differences in the in vitro digestibility of the grass king grass, between broiler and backyard chicken, and cecal fermentation capacity is similar regardless of the exploitation system on which they are located. Was reported that poultry fed diets rich in fiber, decrease their weight gain and feed conversion increased as the level of fiber in the diet increases [27]. This reduction in weight gain and increased feed conversion has been attributed to the decrease nutrient digestibility of the diet, the level of ingredients according fibrous increases.

Respect to total feed cost of the experiment and the cost to produce one kilogram of live weight, the results are presented in Table 5.

More costly treatments were those involving comercial feed without forage (T5), or fresh forage (T3), while less expensive treatments were those involving kitchen waste with and without forage (T1 and T2). This confirms what was reported by Cuca et al. [28] who assert that in the modern poultry industry, $60 \%-70 \%$ of the total production cost is in the area of acquisition of feed. It is evident that the addition of commercial feed production guarantees good results, as found in this study (Table 3), but the production cost is high, resulting in limited use in slow-growing turkeys backyard conditions [29]. Regard to the cost of feed to produce one kilogram of meat in live weight, the cracked corn + fresh forage (T4) was the most expensive treatment, because it was almost exclusively the diet maintenance from 32 weeks of age poultry (Figure 1). This feeding system is very popular in rural areas of the Oaxacan coast [3]. The poor performance was productive that treatment cracked corn + fresh forage, is the reason that the turkeys are considered inefficient, and therefore its production cost and retail price is high [29]. Use of kitchen waste, reduced between 5 to 10 times the cost per kilogram of live weight (Table 5), which makes this feeding strategy as economically viable for small farmers in backyard.

To evaluate the performance of the experimental treatments with respect to all variables, we used a numerical classification to produce an analysis of clusters for semi quantitative data groups. Table 6 shows the results.

Conglomerates analysis indicated that the best treatment considering all the variables analyzed in this study, was kitchen waste + fresh forage (T1), the worst performer was treatment of cracked corn + fresh forage (T4) and the other treatments were in the regular range. These results may be surprising, however one must consider that the matrix considers not only productive responses, also evaluates other as growth and production cost. Under this perspective, it is feasible to produce slow-growing turkeys with kitchen waste + fresh forage. This feeding strategy not get the maximum weight reached by the strategy that includes balanced feed for turkeys + fresh forage, but is competitive enough, from the points of view of production, weight gain and economic analysis. The qualification facilitates the assessment of the type of management that can be given to poultry in backyard 
Table 5. Estimated feeding cost for one kilogram of body weight in slow-growing turkeys with different types of feed.

\begin{tabular}{cccc}
\hline Treatment & Final live weight (g) & ${\text { Total cost feeding } \mathbf{( \$ ) ^ { \mathbf { 1 } }}}$ & Cost per kg body weight $\mathbf{( \$ )}^{\mathbf{1}}$ \\
\hline T1 & 5817.5 & 4.86 & 0.83 \\
T2 & 4777.5 & 2.11 & 0.44 \\
T3 & 6461.3 & 18.13 & 2.81 \\
T4 & 2982.5 & 14.18 & 4.75 \\
T5 & 4976.5 & 20.33 & 4.08 \\
\hline
\end{tabular}

${ }^{1}$ Calculated in US dollars with an exchange rate of \$12.83 Mexican pesos.

Table 6. Matrix to evaluate the behavior of all the variables studied by analysis of conglomerates for semi quantitative data.

\begin{tabular}{lccccc}
\hline \multicolumn{1}{c}{ Variable } & T1 & T2 & T3 & T4 & T5 \\
\hline Daily weight gain $^{1}$ & 2 & 1 & 3 & 1 & 2 \\
Total weight gain $^{1}$ & 2 & 2 & 3 & 1 & 2 \\
Final live weight $^{1}$ & 3 & 2 & 3 & 1 & 2 \\
Total length peak-tail $^{1}$ & 3 & 2 & 2 & 1 & 3 \\
Monthly gain peak-tail length $^{1}$ & 3 & 1 & 1 & 1 & 1 \\
Total length of wings $^{1}$ & 3 & 2 & 2 & 1 & 3 \\
Wings monthly gain length $^{1}$ & 3 & 1 & 1 & 1 & 1 \\
Feeding cost $^{2}$ & 3 & 3 & 1 & 2 & 1 \\
Cost per kg body weight $^{3}$ & 3 & 3 & 2 & 1 & 1 \\
Total $^{\text {Qualification }}{ }^{4}$ & $\mathbf{2 5}$ & $\mathbf{1 7}$ & $\mathbf{1 8}$ & $\mathbf{1 0}$ & $\mathbf{1 6}$ \\
\hline
\end{tabular}

$\mathrm{T} 1$ = kitchen waste + fresh forage; $\mathrm{T} 2$ = kitchen waste; T3 = commercial feed for turkeys + fresh forage; T4 = cracked corn + fresh forage; and T5 = commercial feed for turkeys; ${ }^{1}$ We considered the probability of the average of Tukey's comparison: $\mathrm{A}=3, \mathrm{AB}=2, \mathrm{~B}=1$; ${ }^{2}$ We considered the range of 1 to $100=3,101$ to $200=2,201$ to 300 $=1$; ${ }^{3}$ The range of 1 to $20=3,21$ to $40=2,41$ to $60=1$; ${ }^{4}$ For the rating was considered the interval $9-14=$ Poor, $15-20$ = Fair, $21-27$ = Good.

conditions. Therefore, commercial food will provide better final live weight, but the production cost is high, or, to use kitchen waste, weight gain will be lower, but the costs will be minimized. This type of analysis can be useful to dimensioning the actual feasibility of the treatments.

Considering all the results obtained, we can deduce that it is possible to make use of fresh forage as a viable source of feed for slow-growing turkeys reared in intensive conditions, and consider using kitchen waste to achieve nutritional cover the needs of these birds. Showed a good performance that can further reduce production costs if the inclusion of fresh forage is provided by family labor force which is always available and does not generate any extra cost, or whether by grazing poultry, handling common in traditional poultry production systems [5]. The availability of kitchen waste can be a problem to maintain a small-scale production of turkeys; however this may be obtained from leftover food from restaurants, hotels, supermarkets, markets and households [30]. The addition of fresh forage to the diet and adding kitchen waste to replace commercial feed for turkeys, help save money for backyard producers, and use one of the most abundant resources that have in backyard the producers: the family labor force [31], which could reduce production costs and provide themselves with animal proteins [27].

It is not recommended that kitchen waste are the only food source in chicks, because they will grow more slowly than with other nutritional strategy, Camacho-Escobar et al. [5] report that can be achieved adequate growth of poults offering corn dough with edible plants previously boiled and mashed.

However, a practical problem when using kitchen waste as food for slow-growing turkeys is in how easily it decomposes, causing odors and flies. It has been recommended to apply heat treatment of kitchen waste to be microbiologically safe as an ingredient in animal feed; it is subjected in to a sterilization process as boiling or cooking in steam at a temperature of $100 \mathrm{C}$, thereby avoiding disease transmission [30]. This process is effective, but can result in loss of nutrients by denaturation and increased cost of waste. Techniques such as kitchen 
waste silage [32], could help resolve in part this problem, but research is needed on this topic.

\section{CONCLUSIONS}

Feeding slow-growing turkeys with kitchen waste + fresh forage, it is feasible to obtain adequate productive results as long as kitchen waste be sufficient to cover the nutritional needs of turkeys and forage not generate additional costs labor, which can be solved with family labor force or with grazing.

It is advantageous to use fresh grass as a food supplement in feeding strategies where only commercial feed is used, which implies that it is possible to propose semi stabled production systems for slow-growing turkeys, which have access to commercial food, but also to grazing. Is worth mentioning that exist indications that suggest the importance of fresh forage on productive performance in turkey slow-growing, but more research is needed on the subject. However, studies are needed to evaluate the digestibility that have slow-growing turkeys consuming different forages, and the interaction they may have with different types of diets, to know and better exploiting their synergistic effect in the diet.

\section{REFERENCES}

[1] Pérez-Lara, E. and Camacho-Escobar M.A. (2009) Evaluación de la curvas de crecimiento en guajolote de traspatio con dietas tradicionales. Memorias del 2do. Congreso Internacional en Ciencias Veterinarias y Zootecnia (in CD). Benemérita Universidad Autónoma de Puebla. Facultad de Medicina Veterinaria y Zootecnia, 26 de marzo.

[2] Camacho-Escobar, M.A., Arroyo-Ledezma, L., Pérez-Lara, E., Sánchez-Bernal, E.I. and García-López, J.C. (20092010) Enfermedades y parasitosis asociadas a una explotación intensiva de guajolotes nativos. Ciencias Agrícolas Informa, 19, 56-61.

[3] Camacho-Escobar M.A., Arroyo-Ledezma, J. and Ramirez-Cancino, L. (2008) Diseases of backyard turkeys in the mexican tropics, animal biodiversity and emerging diseases. Annals of New York Academy of Sciences, 1149, 368-370. doi:10.1196/annals.1428.004

[4] Camacho-Escobar, M.A., Lira-Torres, I., Ramírez-Cancino, L., López-Pozos, R. and Arcos-García, J.L. (2006) La avicultura de traspatio en la Costa de Oaxaca, México. Ciencia y Mar, 9, 3-11.

[5] Camacho-Escobar, M.A., Lezama-Nuñez, P.R., Jerez-Salas, M.P., Kollas, J., Vásquez-Dávila, M.A., García-López, J.C., Arroyo-Ledezma, J., Ávila-Serrano, N.Y. and Chávez-Cruz, F. (2011) Avicultura indígena mexicana: Sabiduría milenaria en extinción. Actas Iberoamericanas de Conservación Animal, 1, 375-379.

[6] Camacho-Escobar, M.A., Pérez-Lara, E., Arroyo-Ledezma, J. and Jiménez-Hidalgo, E. (2009) Diferencias y similitudes entre guajolote silvestre y de traspatio (Meleagris gallopavo). Temas de Ciencia y Tecnología, 13, 53-62.

[7] Pérez, R.G. (2003) El arte de criar guajolote mexicano una gran tradición. Revista Imagen Veterinaria, 3, 56-61. http://www.fmvz.unam.mx/fmvz/imavet/v3n4a03/v3n4a0 3.pdf

[8] Tobajas-Andres, F., Juárez-Caratachea, A., Pineda, S. and Figueroa, J.I. (2011) Artrópodos componentes de la dieta de guajolotes de traspatio en el estado de Michoacán, México. Acta Zoológica Mexicana (n.s.), 27, 829-836.

[9] Ramírez-Rivera, E.J., Camacho-Escobar, M.A., GarcíaLópez, J.C., Reyes-Borques, V. and Rodríguez-delaTorre, M. (2012) Sensory analysis of Creole turkey meat whit flash profile method. Open Journal of Animal Science, 2, 1-10. doi:10.4236/ojas.2012.21001

[10] Contino-Esquijerosa, Y. (2007) Estudio de la inclusión de follaje fresco de Morus alba Linn variedad Acorazonada en dietas porcinas. Master Dissertation, University of Matanzas, Cuba, 141.

[11] Camacho-Escobar, M.A., Pérez-Lara, E., Arroyo-Ledezma, J. and Sánchez-Bernal, E.I. (2009) Monitoreo sanitario en guajolotes de traspatio de la Costa de Oaxaca. Memorias de la 34 Convención nacional ANECA (in CD). Asociación Nacional de Especialistas en Ciencias Avícolas de México. Acapulco, Guerrero, 12 al 15 de agosto.

[12] Morales-Salud, T. (2001) Sistema de marcaje, problema de identidad o simple requisito. Memorias del Cuarto Taller Nacional sobre Manejo de Iguanas en Cautiverio. Puerto Ángel, Oaxaca, 2010.

http://www.subcomitedeiguanas.org/PDF\%B4s/taller4.pdf

[13] Secretaría de Agricultura, Ganadería, Desarrollo Rural, Pesca y Alimentación (2001) Norma Oficial Mexicana NOM-062-ZOO-1999 Especificaciones técnicas para la producción, cuidado y uso de los animales de laboratorio. Diario Oficial de la Federación, Miércoles 22 de Agosto. http://www.senasica.gob.mx/?doc=743

[14] Hale, E.B., Scheleidt, W.M. and Schein, M.W. (1969) The behavior of turkeys. In: Hafez, E.S.E., Ed., The Behavior of Domestic Animals, 2nd Edition, Baillière Tindall, London, 559-560.

[15] Association Official of Analytical Chemists (1990) Official methods of analysis. S. Williams, Ed., 15th Edition, Arlington.

[16] Jerez, M.P., Herrera, J. and Vázquez, M.A. (1994) La gallina criolla en los valles centrales de Oaxaca. In: Jeréz, M.A., Herrera, J.G. and Vázquez, M.A., La Gallina Criolla en los Valles Centrales de Oaxaca, Instituto tecnológico agropecuario de Oaxaca No. 23, Nazareno Xoxocotlán, 47-82.

[17] SAS/STAT (1999) User's guide, version 4. 4th Edition, SAS Institute. Inc., Cary.

[18] Steel, R.G.D, Torrie, J.H. and Dickey, D.A. (1997) Principles and procedures of statistics a biomedical approach. 3rd Edition, McGraw-Hill, New York.

[19] Herrera, M.A. (1993) Una mirada al campo de la clasificación numérica. Instituto de Oceanología de Ciencias de Cuba, 12-15.

[20] Sarmiento, F.L., Santos, R.R. and Segura, C.S. (2009) Alimentación no convencional para monogástricos. Ex- 
periencias en el trópico Mexicano. http://www.sian.info.ve/porcinos/publicaciones/encuentro s/viii_encuentro/luiss.htm

[21] Hong, S. (1999) Duckweed versus ground soja beans as supplement for scavening native chickens in an integrated farming system. Livestock Research for Rural Development, 11, 1.

[22] Klasing, K.C. (2005) Poultry nutrition: A comparative approach. Journal of Applied Poultry Research, 14, 426-436.

[23] Toro, C., López, G.A., Álvarez, L.A. and Muñoz, J.E. (2007) Comparación de la capacidad de digestión y fermentación de forrajes en cerdo criollo (Zungo, San Pedreño y Casco de Mula) con cerdos mejorados (cruces de razas o líneas comerciales). Revista Colombia de Ciencias Pecuarias, 20, 600-602.

[24] Mattocks, J. (2009) Nutrición para aves de pastura. Servicio nacional de información de agricultura sostenible. http://es.scribd.com/doc/40781183/Nutricion-para-Aves-d e-Pastura

[25] Bolton, W. (1962) Nutrición aviar. Zaragoza, España, 158.

[26] Huerta-Ruiz, S., Magaña-Sevilla, H. and Camacho-Escobar, M.A. (2009) Aplicación de la técnica de gas in vitro para estimar la digestibilidad de forrajes en aves. Memorias del 2do. Congreso Internacional en Ciencias Veterinarias y Zootecnia [En CD]. Benemérita Universidad Autónoma de Puebla. Facultad de medicina veterinaria y zootecnia. http://bibliotecas.umar.mx/publicaciones/Nutricion\%20an imal.pdf

[27] Aguilar-Ramírez, J., Santos-Ricalde, R., Pech-Martínez,
V. and Montes-Pérez, R. (2000) Utilización de la hoja de Chaya (Cnidoscolus chayamansa) y de Huaxín (Leucaena leucocephala) en la alimentación de aves criollas. Revista Biomédica, 11, 17-24.

[28] Cuca, G.M., Ávila, G.E. and Pro, M.A. (1990) Alimentación de las aves. Colegio de Posgraduados, Chapingo.

[29] Camacho-Escobarm, M.A., Hernandez-Sanchez, V., Ramirez-Cancino L., Sánchez-Bernal, E.I. and Arroyo-Ledezma, J. (2008) Characterization of backyard guajolotes (Meleagris gallopavo) in tropical zones of Mexico. Livestock Research for Rural Development, 20, Article \#50. http://www.cipav.org.co/lrrd//rrd20/4/cama20050.htm

[30] Pond, W.G. and Maner, J.G. (1974) Producción de cerdos en climas templados y tropicales. Editorial Acribia, España, 311.

[31] Hernández, Z.J.S., Pérez, R., Silva, S.E., Hernández, J.A. and González, S. (2011) Los traspatios multifuncionales y sustentables: Sus recursos, su ambiente y las amenazas a su permanencia. In: Perezgrovas, G.R., Rodríguez, G.G. and Zaragoza, M.L., Eds., El Traspatio Iberoamericano Experiencias y Reflexiones en Argentina, Bolivia, Brasil, España, México y Uruguay, Universidad Autónoma de Chiapas Red CONBIAND, San Cristóbal de las Casas, 71-97.

[32] Granja, M.B. and Menéndez, O. (2002) Estabilización anaeróbica de desechos de comida para la elaboración de suplementos alimenticios para cerdos. Bachelor Thesis, Earth University, Guácimo, 45. 